\title{
Impact of increasing crude glycerine levels in diet on growth, carcass traits, body measurements and blood cholesterol in growing Japanese quails
}

\author{
M. Arif', Z. Hayat' ${ }^{1}$, Sh. Sohail' ${ }^{1}$ and M.E. Abd El-Hack ${ }^{2,3}$ \\ ${ }^{1}$ University of Sargodha, University College of Agriculture, Department of Animal Sciences \\ Sargodha 40100, Pakistan \\ ${ }^{2}$ Zagazig University, Faculty of Agriculture, Department of Poultry \\ Zagazig 44511, Egypt
}

KEY WORDS: glycerine, growth, carcass, body measurements, blood cholesterol level, quails

Received: 2 September 2016

Revised: $\quad 31$ January 2017

Accepted: $\quad 8$ March 2017

${ }^{3}$ Corresponding author:

e-mail: m.ezzat@zu.edu.eg or

dr.mohamed.e.abdalhaq@gmail.com

\begin{abstract}
The aim of the study was to evaluate the effect of dietary inclusion of crude glycerine on growth performance, carcass traits, body measurements and blood cholesterol level of growing Japanese quails. In total 375 one-dayold Japanese quails were randomly divided into five equal groups under complete randomized design. Experimental groups were as follows: T1: basal diet (without glycerine addition), T2: basal diet $+2.5 \%$ glycerine, T3: basal diet $+5 \%$ glycerine, T4: basal diet $+7.5 \%$ glycerine, and T5: basal diet + $10 \%$ glycerine. Each treatment was replicated 5 times, 15 birds in each replicate. It was observed that glycerine supplementation did not significantly $(P>0.05)$ affect the feed intake and body weight of birds. Dietary inclusion of glycerine at a dose of 2.5 and $5 \%$ had positive impact on feed conversion ratio (quadratic, $P=0.021$ ) in comparison to control group. Glycerine inclusion in the diet did not affect total blood cholesterol level. Furthermore, neither carcass traits nor body measurements were statistically influenced by the different inclusion levels of glycerine. So, it could be stated that in order to obtain positive effects on quail growth performance, crude glycerine could be used in diets as a source of energy at levels of 2.5 and $5 \%$.
\end{abstract}

\section{Introduction}

Glycerine, a by-product of popular nowadays biodiesel production, is easy available and can possibly be used as a new energy feed ingredient (Koreleski et al., 2011). Currently, in Europe it is produced and consumed about $80 \%$ of total global biodiesel production (Pond et al., 2005). Using biodiesel byproducts in poultry feeding could reduce feed costs and consequently enhance profitability. Glycerine or glycerol is an odourless, colourless sweet syrupy liquid. In the living organisms, glycerine is a part of all triglyceride molecules present in animal and plant tissues (Pond et al., 2005). It was discovered almost 250 years ago as a result of simple chemical reaction. Commercially, it is synthetized from propylene or it is obtained during saponification process as a by-product (Morrison, 2000). A huge amount of glycerine is produced mainly in USA and Europe. It is widely used in food, cosmetic, pharmaceutical and others industries. In the past, glycerine was used to treat ketosis in animals (Johnson, 1954). 
Fisher et al. (1971) observed its positive impact on total energy intake. It was also estimated that glycerine could partially replace maize in poultry feed if its market price is encouraging (Terré et al., 2011). Alvarenga et al. (2012) found that every kg of clean glycerol contains $4100 \mathrm{kcal}$ gross energy, so it could be considered as an energy-rich additive to poultry diet. Its energy potential was earlier observed by Kroupa et al. (2011) who fed broiler chickens with glycerine.

Glycerol as a water-soluble molecule, with small molecular weight (Guyton, 1991), can be easily absorbed in the gastrointestinal tract (Lin, 1976). After absorption in the intestine, glycerol is transformed to glucose through gluconeogenesis via the cycle of citric acid and glycolysis (Rosebrough et al., 1980). Under basic conditions, about $60 \%$ of glycerol is converted into energy (Robergs and Griffin, 1998). Generally it is metabolized in the kidneys and liver (Bernardino et al., 2015). The amount of glucose carbon derived from glycerol is dependent on glycerol utilization and metabolic state (Baba et al., 1995). Ustundag et al. (2013) fed broilers diets containing $2.5 \%$ glycerine and observed increased feed intake, but no differences in feed efficiency (level of glycerine supplementation and feeding period did not affect this parameter). Henz et al. (2014) revealed that dietary level of crude glycerine up to $6.06 \%$ resulted in better body weight gains without influencing carcass traits. Moreover, higher levels of glycerine (12 and 15\%) resulted in lower weight gains, and increasing crude glycerine level quadratically increased feed intake at 10 days of age. Mandalawi et al. (2014) investigated the effects of different glycerine sources and levels in broiler diets. A $2 \times 2$ factorial design was used with four levels of inclusion $(2.5,5,7.5$ and $10 \%)$, along with two sources of glycerine. It was found that raw glycerine could be efficiently utilized when included at levels up to $10 \%$ in the starter diet phase. Romano et al. (2014) observed a linear interaction between glycerine levels and bird age on daily feed intake. Bernardino et al. (2015) studied the influence of pure and semi-pure glycerine addition with varying levels $\left(0,17.5,35,52.5\right.$ and $\left.70 \mathrm{~g} \cdot \mathrm{kg}^{-1}\right)$ on broiler performance. The best body weight gain was seen in the group treated with $35.50 \mathrm{~g} \cdot \mathrm{kg}^{-1}$ semi-pure glycerine. So, levels of $70 \mathrm{~g} \cdot \mathrm{kg}^{-1}$ of pure glycerine and $35.5 \mathrm{~g} \cdot \mathrm{kg}^{-1}$ of semi-pure glycerine were the best for broiler performance. Feed conversion ratio was worse after the addition of $70 \mathrm{~g} \cdot \mathrm{kg}^{-1}$ glycerine to the diet, but other production parameters and egg quality were not affected (Mandalawi et al., 2015).
The aim of the present study was to determine the effect of graded levels of crude glycerine as a source of energy on growth performance, carcass characteristics, body measurements and blood cholesterol level in growing Japanese quails.

\section{Material and methods}

The experiment was conducted at Avian Research Farm, Department of Animal Sciences, University College of Agriculture, University of Sargodha (Pakistan). All procedures were carried out according to the procedures of Local Experimental Animal Care Committee, and approved by the Ethics Committee of Department of Animal Sciences, University College of Agriculture, University of Sargodha (Pakistan).

\section{Birds, housing and management}

In the 6-week experiment 375 one-day-old Japanese quail chicks obtained from internal hatchery in the Avian Research farm were used. Birds were randomly divided into five treatment groups. Each treatment was replicated 5 times, with 15 birds in each replicate. Chicks were individually weighed for the initial body weight by an electrical weighing balance and then randomly allotted into replicates. Managerial practices were maintained for birds to provide proper environmental conditions. Quails were housed in galvanized wire cages with a flat deck; 15 birds in each cage $(3 \times 2 \times 0.5 \mathrm{~m})$ in a well-ventilated building. All animals were reared under similar environmental and management order. Proper hygienic and sanitary conditions were maintained during whole experiment. Temperature was kept at $37{ }^{\circ} \mathrm{C}$ during first 3 days for brooding purpose and then gradually reduced daily by $1{ }^{\circ} \mathrm{C}$ and was set at $31^{\circ} \mathrm{C}$ for week 2 and 3 , and $28{ }^{\circ} \mathrm{C}$ for the week 4 . Light was available for $24 \mathrm{~h}$. Clean and fresh drinking water through nipple drinkers was available round-the-clock ad libitum.

\section{Experimental diets}

Five isocaloric $\left(\mathrm{ME}=2900 \mathrm{kcal} \cdot \mathrm{kg}^{-1}\right)$ and isonitrogenous $(20 \% \mathrm{CP})$ diets were formulated with increasing level of glycerine. Experimental groups were as follows: T1: basal diet (without glycerine addition), T2: basal diet $+2.5 \%$ glycerine, $\mathrm{T} 3$ : basal diet $+5 \%$ glycerine, $\mathrm{T} 4$ : basal diet $+7.5 \%$ glycerine, and T5: basal diet $+10 \%$ glycerine (Table 1). Birds were randomly allotted to each group. Crude glycerine used in the present study was purchased from 
Table 1. Composition of experimental diets

\begin{tabular}{|c|c|c|c|c|c|}
\hline \multirow{2}{*}{ Indices } & \multicolumn{5}{|l|}{ Group $^{1}$} \\
\hline & $\mathrm{T} 1$ & $\mathrm{~T} 2$ & T3 & T4 & T5 \\
\hline \multicolumn{6}{|l|}{ Ingredients, $\mathrm{g} \cdot \mathrm{kg}^{-1}$} \\
\hline glycerine $\left(3620 \mathrm{kcal} \cdot \mathrm{kg}^{-1}\right)$ & 0.0 & 25.0 & 50.0 & 75.0 & 100.0 \\
\hline maize & 576.7 & 593.6 & 564.6 & 527.9 & 492.9 \\
\hline sunflower meal $(26 \% \mathrm{CP})$ & 64.4 & 0.0 & 5.6 & 16.4 & 27.2 \\
\hline $\begin{array}{l}\text { soyabean oil } \\
\left(8500 \mathrm{kcal} \cdot \mathrm{kg}^{-1}\right)\end{array}$ & 20.0 & 1.3 & 0.0 & 0.0 & 0.0 \\
\hline soyabean meal $(45 \% \mathrm{CP})$ & 298.8 & 335.4 & 337.1 & 336.1 & 335.2 \\
\hline limestone & 11.6 & 11.7 & 11.7 & 11.6 & 11.5 \\
\hline mono-calcium phosphate & 17.3 & 17.5 & 17.5 & 17.5 & 17.6 \\
\hline salt & 3.8 & 3.9 & 3.9 & 3.9 & 3.9 \\
\hline vitamin premix ${ }^{2}$ & 2.0 & 2.0 & 0.0 & 2.0 & 2.0 \\
\hline methionine & 2.7 & 2.8 & 2.8 & 2.8 & 2.9 \\
\hline threonine & 1.2 & 1.2 & 1.2 & 1.2 & 1.2 \\
\hline lysine sulphate & 1.2 & 5.3 & 5.3 & 5.3 & 5.3 \\
\hline choline chloride & 0.3 & 0.3 & 0.3 & 0.3 & 0.3 \\
\hline \multicolumn{6}{|l|}{ Calculated composition ${ }^{3}, \%$} \\
\hline crude protein & 20.0 & 20.0 & 20.0 & 20.0 & 20.0 \\
\hline lysine & 1.60 & 1.59 & 1.61 & 1.60 & 1.60 \\
\hline methionine + cysteine & 0.89 & 0.89 & 0.88 & 0.89 & 0.89 \\
\hline $\mathrm{Ca}$ & 0.85 & 0.85 & 0.85 & 0.85 & 0.85 \\
\hline & 0.45 & 0.45 & 0.45 & $5 \quad 0.45$ & 0.46 \\
\hline $\mathrm{ME}, \mathrm{kcal} \cdot \mathrm{kg}^{-1}$ & 2900 & $2900 \quad 2$ & 2900 & 29002 & 2900 \\
\hline
\end{tabular}

1 groups were fed: T1 - basal diet (without glycerine addition), T2 - basal diet $+2.5 \%$ glycerine, T3 - basal diet $+5 \%$ glycerine, $\mathrm{T} 4$ - basal diet $+7.5 \%$ glycerine, $\mathrm{T} 5$ - basal diet $+10 \%$ glycerine; ${ }^{2}$ growth vitamin and mineral premix: each $1 \mathrm{~kg}$ consists of: IU: vit. $A 1500$, vit. E 8; ICU: vit. $D_{3} 200$; mg: vit. $B_{1} 1$, vit. $B_{2} 5.5$, vit. $B_{6} 2.2$ vit. $B_{12} 0.02$, vit. $K_{3} 2$, folic acid 0.50 , pantothenic acid 13 , niacin 37 , choline chloride 500, Mg 66, Zn 55, Cu 6, K 3.2, I 1.2, Fe 27.5, biotin $0.1 ;{ }^{3}$ calculated according to NRC (1994)

Faisal Traders (Sargodha, Pakistan) and consisted of: \%: glycerol 63.52 , moisture 8.15 , methanol 1.23, free fatty acids 1.67 , crude protein 0.79 , ash 4.45 , crude fibre 0.30 , fat 8.54 and salt 2.35 ; apparent metabolizable energy was $3620 \mathrm{kcal} \cdot \mathrm{kg}^{-1}$.

\section{Growth performance}

The chicken initial body weight was determined just before shifting into cages. After that, each replicate was weighted weekly using an electrical weighing balance. Daily feed intake (FI) record was kept for each replicate. Feed conversion ratio (FCR) was calculated on weekly basis from feed intake during whole week and body weight gain (BWG) per replicate. There was no mortality detected.

\section{Proximate analysis of feed samples}

The proximate analysis of tested feeds was carried out according to AOAC International (2003) for determination of dry matter (ID 930.15), organic matter (ID 942.05), crude protein (ID 954.01), ether extract (ID 945.16) and crude fibre (ID 978.10) (Table 2).
Table 2. Proximate analysis of experimental diets

\begin{tabular}{|c|c|c|c|c|c|}
\hline \multirow{2}{*}{$\begin{array}{l}\text { Determined } \\
\text { analysis }^{1}, \%\end{array}$} & \multicolumn{5}{|c|}{ Group $^{2}$} \\
\hline & $\mathrm{T} 1$ & $\mathrm{~T} 2$ & T3 & $\mathrm{T} 4$ & T5 \\
\hline Dry matter & 91.14 & 89.18 & 89.19 & 88.67 & 86.68 \\
\hline Crude protein & 20.78 & 20.56 & 20.78 & 20.56 & 20.78 \\
\hline Ether extract & 10.85 & 10.18 & 11.30 & 11.06 & 12.21 \\
\hline Ash & 6.55 & 5.61 & 5.99 & 6.46 & 6.40 \\
\hline Crude fibre & 3.00 & 2.98 & 2.95 & 2.98 & 2.97 \\
\hline $\begin{array}{l}\text { Nitrogen free } \\
\text { extract }\end{array}$ & 49.96 & 49.85 & 48.17 & 50.64 & 44.32 \\
\hline
\end{tabular}

${ }^{1}$ according to AOAC International (2003); ${ }^{2}$ see Table 1

\section{Total cholesterol content (TC)}

At the end of the experiment, 10 quails from each group ( 2 from each replicate; one male and one female) were randomly chosen and slaughtered by severing the jugular vein. Blood samples were collected individually. After clotting at room temperature for $3 \mathrm{~h}$, blood samples were centrifuged at $3000 \mathrm{rpm}$ at room temperature for $10 \mathrm{~min}$ and then serum was carefully collected and stored at $-20{ }^{\circ} \mathrm{C}$ until further analysis. Samples were analysed for serum cholesterol level by kit method according to Akiba et al. (1982).

\section{Slaughtering data}

At the end of the experiment, two birds were randomly selected from each replicate and weighed individually for live weight and then slaughtered. The bird's head, feathers and internal organs were removed to calculate the carcass weight. The weights of the thigh, breast, liver, gizzard, heart, spleen and bursa of Fabricius were recorded and expressed as $\mathrm{g}$ of slaughter weight.

\section{Statistical analysis}

Data were subjected to one-way analysis of variance (ANOVA) using the GLM procedure of SAS (version 9.2, 2008; SAS Institute Inc., Cary, NC, USA). The differences among means were determined using the Tukey's post-hoc test. The measures were treated statistically significant at $P<0.05$ unless otherwise stated.

\section{Results and Discussion}

\section{Growth performance}

Inclusion of dietary glycerine had no linear or quadratic effect $(P>0.05)$ on FI (Table 3$)$. This result might be attributed to glycerine composition, varying dietary level, period of supplementation and diet composition. Similar results were obtained by Erol et al. (2009) who fed quails different levels 
Table 3. Effect of dietary glycerine level on growth performance traits and blood total cholesterol level in growing Japanese quails

\begin{tabular}{|c|c|c|c|c|c|c|c|c|}
\hline \multirow{2}{*}{ Indices $^{1}$} & \multicolumn{5}{|l|}{ Group $^{2}$} & \multirow{2}{*}{ SEM } & \multicolumn{2}{|c|}{$P$-value } \\
\hline & $\mathrm{T} 1$ & T2 & T3 & T4 & T5 & & linear & quadratic \\
\hline$\overline{F l}$, g/quail & 857.9 & 794.9 & 803.3 & 832.9 & 812.1 & 3.51 & 0.891 & 0.421 \\
\hline BWG, g/quail & 212.4 & 223.8 & 223.6 & 223.9 & 223.6 & 4.54 & 0.658 & 0.621 \\
\hline$F C R, g$ feed $\cdot g^{-1}$ gain & $4.16^{\mathrm{a}}$ & $3.55^{\mathrm{b}}$ & $3.60^{\mathrm{b}}$ & $3.81^{\mathrm{ab}}$ & $3.74^{\mathrm{ab}}$ & 0.16 & 0.090 & 0.021 \\
\hline TC blood level, $\mathrm{mg} \cdot \mathrm{dl}^{-1}$ & 149.8 & 146.4 & 126.3 & 148.1 & 167.4 & 13.56 & 1.321 & 0.654 \\
\hline
\end{tabular}

${ }^{1} \mathrm{FI}$ - feed intake, BWG - body weight gain, FCR - feed conversion ratio, TC - total cholesterol; ${ }^{2}$ see Table 1 ; ab - means with different superscripts within a row are significantly different $(P \leq 0.05)$

of glycerine and observed no significant effect on FI. McLea et al. (2011) also reported no significant influence on FI with glycerine inclusion in broiler diets. Recently, Bernardino et al. (2015) also postulated that glycerine had no statistical impact on quail FI. In contrast, Yalçin et al. (2010) observed a significant increase in FI in laying hens fed diet enriched with glycerine.

The obtained results showed that dietary glycerine inclusion had no statistical effect $(P>0.05)$ on quail BWG (Table 3). This result could be attributed to the glycerine high energy content, besides its content of other nutrients. Our results are in line with the findings of Erol et al. (2009). Similarly, Gasparino et al. (2012) demonstrated that glycerine had no statistical effect on Japanese quail BWG. Cerrate et al. (2006) assured that glycerol had no significant effect on broiler BWG. Contrarily, Sehu et al. (2013) found that glycerine had significant impact on broiler chicken BWG and connected it with $\mathrm{AME}_{\mathrm{n}}$ content in glycerine which is $10 \%$ higher than maize. Bernardino et al. (2015) suggested that these differences might be due to dissimilarities in energy content and other substances present in glycerine like methanol.

Feed conversion ratio (FCR) was affected by glycerine inclusion in quail diets (quadratic, $P=0.021$ ). The highest FCR values were observed in groups with 2.5 and $5 \%$ inclusions of glycerine in comparison to control and other experimental groups. Improved
FCR might result from simple chemical structure of glycerine which is easily digested (Topal and Ozdogan, 2013). Possibly, smaller molecular structure/weight of glycerol could have been the reason for its better absorption through gastrointestinal tract and then its conversion to glucose through gluconeogenesis pathway or energy through citric acid cycle and glycolysis. Higher energy amount of glycerol may share in improving FCR. Results of the present study are in line with the findings of Bernardino et al. (2015) who noticed that including crude glycerine in diets improved FCR in broilers and concluded that this was due to the low concentration of methanol $\left(20.62 \mathrm{mg} \cdot 1^{-1}\right)$ in glycerine preparation. Furthermore, Mandalawi et al. (2014) stated that FCR improved with glycerine addition in broiler diets from 1 to 21 day of age. Contradictive results were obtained by Cerrate et al. (2006) who demonstrated that glycerine had no impact on FCR in poultry. Also, Rosebrough et al. (1980) found no significant effect of glycerol on FCR in turkey hens. Coşkun et al. (2007) assured that FCR $\left(\mathrm{kg}\right.$ egg $\cdot \mathrm{kg}$ feed $\left.{ }^{-1}\right)$ in experimental groups fed glycerol-enriched $\left(50\right.$ and $\left.100 \mathrm{~g} \cdot \mathrm{kg}^{-1}\right)$ diets for 16 weeks was not statistically different from the control group.

\section{Carcass characteristics}

No linear or quadratic differences within breast yield, leg quarter yield, carcass weight, liver, heart,

Table 4. Effect of dietary glycerine level on carcass characteristics of growing Japanese quails

\begin{tabular}{|c|c|c|c|c|c|c|c|c|}
\hline \multirow{2}{*}{ Indices } & \multicolumn{5}{|l|}{ Group ${ }^{1}$} & \multirow{2}{*}{ SEM } & \multicolumn{2}{|c|}{$P$-value } \\
\hline & $\mathrm{T} 1$ & $\mathrm{~T} 2$ & T3 & T4 & T5 & & linear & quadratic \\
\hline Breast yield, g & 89.45 & 89.06 & 89.521 & 88.692 & 87.854 & 1.89 & 1.213 & 0.623 \\
\hline Thigh yield, g & 46.13 & 51.57 & 47.44 & 48.25 & 46.56 & 3.46 & 0.655 & 0.325 \\
\hline \multicolumn{9}{|l|}{ Weight, g } \\
\hline carcass & 135.59 & 140.63 & 136.96 & 136.94 & 134.41 & 4.90 & 0.654 & 0.953 \\
\hline gizzard & 3.05 & 3.20 & 3.48 & 4.21 & 3.70 & 0.37 & 0.542 & 0.333 \\
\hline heart & 1.90 & 1.98 & 1.91 & 1.91 & 1.95 & 0.07 & 0.879 & 0.215 \\
\hline liver & 4.40 & 4.63 & 3.96 & 4.93 & 4.77 & 0.28 & 0.655 & 0.544 \\
\hline spleen & 0.14 & 0.15 & 0.13 & 0.16 & 0.14 & 0.02 & 1.025 & 0.658 \\
\hline bursa of Fabricius & 0.18 & 0.23 & 0.23 & 0.20 & 0.24 & 0.02 & 0.956 & 0.948 \\
\hline
\end{tabular}


Table 5. Effect of dietary glycerine level on body measurements of growing Japanese quails

\begin{tabular}{|c|c|c|c|c|c|c|c|c|}
\hline \multirow{2}{*}{ Indices } & \multicolumn{5}{|c|}{ Group ${ }^{1}$} & \multirow{2}{*}{ SEM } & \multicolumn{2}{|c|}{$P$-value } \\
\hline & $\mathrm{T} 1$ & $\mathrm{~T} 2$ & T3 & T4 & T5 & & linear & quadratic \\
\hline Body length, cm & 32.35 & 31.70 & 31.10 & 31.20 & 32.30 & 0.33 & 0.215 & 0.613 \\
\hline Breast width, cm & 1.41 & 1.47 & 1.42 & 1.45 & 1.46 & 0.03 & 0.332 & 0.686 \\
\hline Drumsticks length, $\mathrm{cm}$ & 5.61 & 5.64 & 5.77 & 5.82 & 5.56 & 0.05 & 0.155 & 0.195 \\
\hline Sternum length, cm & 6.45 & 6.76 & 6.65 & 6.60 & 6.58 & 0.06 & 0.525 & 0.154 \\
\hline Shank diameter, cm & 1.96 & 1.76 & 1.80 & 1.69 & 1.57 & 1.02 & 1.000 & 0.233 \\
\hline Shank length, cm & 3.91 & 3.91 & 3.91 & 4.04 & 4.04 & 0.02 & 0.365 & 0.511 \\
\hline Intestinal length, cm & 71.00 & 69.20 & 68.00 & 70.90 & 72.60 & 1.69 & 0.654 & 0.945 \\
\hline Intestinal weight, g & 9.64 & 9.60 & 8.81 & 10.20 & 9.47 & 0.46 & 0.615 & 0.648 \\
\hline
\end{tabular}

${ }^{1}$ see Table 1

gizzard, bursa of Fabricius and spleen were observed among experimental groups (Table 4). These results are in line with the findings of Cerrate et al. (2006) who observed no effect of glycerine on carcass characteristics of broiler chickens and attributed it to the limited use of glycerol in the diet. Similar results were also obtained by Topal and Ozdogan (2013) who reported no differences in carcass characteristics of broilers from experimental groups. Abd-Elsamee et al. (2010) found that varying levels of glycerol in the diet did not significantly affect dressing percentage, internal organs percentage or immune organ weights in broilers in comparison to the control group. Results of this study are in contrast to those of Bernardino et al. (2015) who observed significant influence of glycerine on broiler breast yield and leg quarter yield. Moreover, Coşkun et al. (2007) stated that gizzard, liver and heart weights were lower in broilers from the experimental group fed diet enriched with $50 \mathrm{~g}$ of glycerol per $\mathrm{kg}$ of diet and higher in animals from the group fed $100 \mathrm{~g}$ of glycerol per $\mathrm{kg}$ of diet.

\section{Body measurements}

No linear or quadratic influences of glycerine inclusion were observed on body measurements including body length, breast width, shank diameter, shank length, sternum length, drumsticks length, intestinal weight and intestinal length (Table 5).

\section{Blood total cholesterol}

Glycerine inclusion did not exert any influence on total cholesterol blood content in quails (Table 3 ). Such result is in line with findings reported by Topal and Ozdogan (2013) who confirmed that glycerol did not affect the total cholesterol level in broilers. In this context, Yalçin et al. (2010) noticed no significant influence of dietary glycerol on blood cholesterol level in laying hens.

\section{Conclusions}

Very popular bio-product of biodiesel production - crude glycerine - could be used as a source of energy in quail diets. The most positive effects on growth performance can be obtained with 2.5 and $5 \%$ addition of glycerine.

\section{References}

Abd-Elsamee M.O., Abdo Z.M.A., El-Manylawi M.A.F., Salim I.H., 2010. Use of crude glycerin in broiler diets. Egypt. Poult. Sci. J. 30, 281-295

Akiba Y., Jensen L.S., Barb C.R., Kraeling R.R., 1982. Plasma estradiol, thyroid hormones, and liver lipid content in laying hens fed diffent isocaloric diets. J. Nutr. 112, 299-308

Alvarenga R.R., Lima E.M.C, Zangeronimo M.G., Rodrigues P.B., Bernardino V.M.P., 2012. Use of glycerine in poultry diets. World Poult. Sci. J. 68, 637-644, https://doi.org/10.1017/ S0043933912000773

AOAC International, 2003. Official Methods of Analysis. AOAC International. $17^{\text {th }}$ Edition, $2^{\text {nd }}$ revision. Gaithersburg, MD (USA)

Baba H., Zhang X.J., Wolfe R.R., 1995. Glycerol gluconeogenesis in fasting humans. Nutrition 11, 149-153

Bernardino V.M.P., Rodrigues P.B., de Freitas R.T.F., Gomide E.M., Makiyama L., Bueno R.S., de Oliveira D.H., Lara L.J., 2015. Sources and levels of glycerin for broilers from 22 to 35 days. Afr. J. Agric. Res. 10, 1259-1265

Cerrate S., Yan F., Wang Z., Coto C., Sacakli P., Waldroup P.W., 2006. Evaluation of glycerine from biodiesel production as a feed ingredient for broilers. Int. J. Poult. Sci. 5, 1001-1007, https://doi. org/10.3923/ijps.2006.1001.1007

Coşkun B., Şehu A., Küçükersan S., Köksal B.H., 2007. Use of biodiesel by-product glycerol in poultry rations. In: Proceedings of the IV National Animal Nutrition Congress. Bursa (Turkey), pp. 24-31

Erol H., Yalçin S., Midilli M., Yalçin S., 2009. The effects of dietary glycerol on growth and laying performance, egg traits and some blood biochemical parameters in quails. Rev. Med. Vet. 160, 469-476

ESA (European System of National and Regional Accounts), 2010. http:// ec.europa.eu/eurostat/web/national-accounts/methodology

Fisher L.J., Erfle J.D., Sauer F.D., 1971. Preliminary evaluation of the addition of glucogenic materials to the rations of lactating cows. Can. J. Anim. Sci. 51, 721-727, https://doi.org/10.4141/ cjas71-097 
Gasparino E., Oliveira Neto A.R., Del Vesco A.P., Pires A.V., Batista E., Voltolini D.M., Souza K.R.S., 2012. Expression of growth genes in response to glycerol use in Japanese quail diets. Genet. Mol. Res. 11, 3063-3068, https://doi. org/10.4238/2012.August.31.3

Guyton A.C., 1991. Textbook of Medical Physiology. W.B. Saunders Co., Philadelphia, PA (USA)

Henz J.R., Nunes R.V., Eyng C., Pozza P.C., Frank R., Schone R.A., Oliveira T.M.M., 2014. Effect of dietary glycerin supplementation in the starter diet on broiler performance. Czech J. Anim. Sci. 59, 557-563

Johnson R.B., 1954. The treatment of ketosis with glycerol and propylene glycol. Cornell Vet. 44, 6-21

Koreleski J., Świątkiewicz S., Arczewska-Włosek A., 2011. Rapeseed cake, glycerin and distillers dried grains with solubles used simultaneously as a source of nutrients for hens in their second laying season. Ann. Anim. Sci. 11, 125-133

Kroupa L., Suchý P., Straková E., Herzig I., 2011. Glycerol as source of energy in broiler chicken fattening. Acta Vet. Brno 80, 157-164, https://doi.org/10.2754/avb201180020157

Lin M.H., Romsos D.R., Leveille G.A., 1976. Effect of glycerol on lipogenic enzyme activities and on fatty acid synthesis in the rat and chicken. J. Nutr. 106, 1668-1677

Mandalawi H.A., Kimiaeitalab M.V., Obregon V., Menoyo D., Mateos G.G., 2014. Influence of source and level of glycerin in the diet on growth performance, liver characteristics, and nutrient digestibility in broilers from hatching to 21 days of age. Poult. Sci. 93, 2855-2863, https://doi.org/10.3382/ps.2014-04156

Mandalawi H.A., Lázaro R., Redón M., Herrera J., Menoyo D., Mateos G.G., 2015. Glycerin and lecithin inclusion in diets for brown egg-laying hens: Effects on egg production and nutrient digestibility. Anim. Feed Sci. Technol. 209, 145-156, https://doi.org/10.1016/j.anifeedsci.2015.07.019

Mclea L., Ball M.E.E., Kilpatrick D., Elliott C., 2011. The effect of glycerol inclusion on broiler performance and nutrient digestibility. Br. Poult. Sci. 52, 368-375, https://doi.org/10.1080/0007166 8.2011 .584520

Morrison L.R., 2000. Glycerol. In: Kirk-Othmer Encyclopedia of Chemical Technology. John Wiley \& Sons, Inc., Hoboken, NJ (USA), https://doi.org/10.1002/0471238961.0712250313151818.a01
NRC, 1994. Nutrient Requirements of Poultry. $9^{\text {th }}$ revised Edition. National Academy Press, Washington, DC (USA)

Pond W.G., Church D.C., Pond K.R., Schoknecht A., 2005. Basic Animal Nutrition and Feeding. $5^{\text {th }}$ Edition. Wiley \& Sons, Inc., Hoboken, NJ (USA)

Robergs R.A., Griffin S.E., 1998. Glycerol: biochemistry, pharmacokinetics and clinical and practical applications. Sports Med. 26, 145-167, https://doi.org/10.2165/00007256-19982603000002

Romano G.G., Menten J.F.M., Freitas L.W., Lima M.B., Pereira R., Zavarize K.C., Dias C.T.S., 2014. Effects of glycerol on the metabolism of broilers fed increasing glycerine levels. Braz. J. Poult. Sci. 16, 97-106, https://doi.org/10.1590/S1516635X2014000100014

Rosebrough R.W., Geis E., James P., Ota H., Whitehead J., 1980. Effects of dietary energy substitutions on reproductive performance, feed efficiency and lipogenic enzyme activity on large white turkey hens. J. Poult. Sci. 59, 1485-1492, https://doi. org/10.3382/ps.0591485

Sehu A., Kucukersan S., Coskun B., Koksal B.H., 2013. Effects of graded levels of crude glycerine addition to diets on growth performance, carcass traits and economic efficiency in broiler chickens. Kafkas Univ. Vet. Fak. Derg. 19, 569-574, https:// doi.org/10.9775/kvfd.2012.8369

Terré M., Nudda A., Casado P., Bach A., 2011. The use of glycerine in rations for light lamb during the fattening period. Anim. Feed. Sci. Technol. 164, 262-267, https://doi.org/10.1016/j.anifeedsci. 2010.12 .008

Topal E., Ozdogan M., 2013. Effects of glycerol on the growth performance, internal organ weights, and drumstick muscle of broilers. J. Appl. Poult. Res. 22, 146-151, https://doi.org/10.3382/ japr.2012-00589

Ustundag A.O., Tuzun A.E., Ozdogan M., 2013. Effect of glycerol supplemented diet fed different ages on growth performance and some blood parameters in Japanese quails. J. Int. Sci. Pub. Agric. Food 1, Part 1, 4-10

Yalçin S., Erol H., Özsoy B., Onbaşılar İ., Yalçin S., Üner A., 2010. Effects of glycerol on performance, egg traits, some blood parameters and antibody production to SRBC of laying hens. Livest. Sci. 129, 129-134, https://doi.org/10.1016/j. livsci.2010.01.014 